\title{
Kualitas Pelayanan BPJS Pada Klinik Di Kota Pekanbaru
}

\author{
Hadiyati \\ Jurusan Manajemen Fakultas Ekonomi \\ Universitas Lancang Kuning \\ Jl. Yos Sudarso KM. 08 Rumbai - Pekanbaru
}

\begin{abstract}
Abstract: Ministry of Social Security Agency (BPJS) is the Social Security Agency established by the government to provide for Public Health Insurance, National Health Insurance (JKN) is a public health program to realize the health services in accordance with medical needs. BPJS Health Care not for all Indonesian people. Public complaints against the service based on the results of the study proved to be due for service procedures that are less well applied and also because of the service provided is not using the right people and facilities are also incomplete, although the specified low cost but not efficient in making the community recover of the disease.
\end{abstract}

Keywords: Quality of Service, BPJS

Indonesia merupakan negara yang sedang berkembang dan memiliki penerapan sistem demokrasi yang langsung, dimana pemerintah yang memimpin negara ini secara langsung ditentukan oleh rakyat. Pemerintah yang memiliki visi dan misi yang sama dengan dominasi rakyat menjadi pilihan rakyat. Sesuai dengan kondisi dan keinginan berdiri sebuah negara salah satunya adalah kesejahteraan.

Kesejahteraan rakyat menjadi bahan bahan kajian, dimana salah satu indikator kesejahteraan rakyat adalah tingkat harapan hidup, dimana rakyat berhak untuk hidup sehat dan juga berumur panjang. Untuk mencoba bagaimana rakyat dapat berumur panjang dan sehat selalu, maka pemerintah menyediakan fasilitas kesehatan.

Fasilitas pelayanan kesehatan yang terdiri dari berbagai tingkatan mulai tingkat desa sampai dengan tingkat ibukota negara. Fasilitas ini juga tidak hanya disediakan oleh pemerintah, juga disediakan oleh pihak swasta. Dimana dewasa ini hampir seluruh desa hingga ke penjuru daerah sudah memiliki fasilitas kesehatan.

Klinik menjadi salah satu fasilitas kesehatan yang disediakan pihak swasta. Semula sebelum adanya program asuransi kesehatan berupa BPJS, klinik-klinik kurang berkembang dan saat ini sudah ramai bermunculan dan menjadikan klinik bagai jamur yang tumbuh di musim hujan.
Permasalahannya berkaitan dengan masalah dengan tumbuhnya banyak klinik bagaimana kualitas pelayanan yang diberikan kepada masyarakat. Hal ini menjadi salah satu pertanyaan yang penting mendapatkan perhatian, agar harapan rakyat mendapatkan pelayanan kesehatan yang baik akan dapat terwujud.

Program BPJS menjadi salah satu program yang besar, dimana peran pemerintah sebagai pemberi ide berdiriya BPJS menjadikan BPJS mendapatkan dukungan penuh dari pemerintah. Rakyat diwajibkan untuk membayar sejumlah uang setiap bulannya dengan konsep kesetiakawanan, baik sakit maupun tidak sakit harus membayar dan nantinya digunakan sebagai bentuk antisipasi untuk menghadapi pembayaran pada saat sakit.

Memang sebelumnya diketahui yang menjadi masalah bagi rakyat enggan ke rumah sakit karena mereka tidak memiliki anggaran untuk berobat. Dimana pada saat sakit inilah biaya untuk berobat memang diperlukan. Pihak rumah sakit tidak mau melayani pasien apabila tidak adanya jaminan dari keluarga pasien untuk biaya perobatan anggota keluarganya yang sakit.

Persoalan pelayanan yang diberikan klinik akhir-akhir ini menjadi sorotan, dimana beberapa kendala dalam pelayanan menjadikan fasilitas kesehatan seperti klinik mendapatkan kritik yang pedas dari 
rakyat, adanya kesan berobat pada klinik yang kurang optimal dan kurang mendapatkan kesembuhan dan obat yang kurang tersedia dan pasien harus mengeluarkan uang untuk membeli obat sendiri ke apotik dan masalah kesiapan petugas medis memberikan pelayanan kepada pasien.

Kota Pekanbaru merupakan salah satu wlayah yang menerapkan BPJS kesehatan kepada warganya, pelayanan kesehatan bermula pada perawatan kesehatan pada fasilitas pertama yakni puskesmas atau klinik umum. Hal ini dimaksudkan agar pelayanan tidak membludak pada rumah sakit, namun jika kondisi darurat dapat langsung ke rumah sakit yang ditunjuk berdasarkan surat pengantar dari puskesmas atau klinik. Fenomena menarik mengenai klinik di Kota Pekanbaru semakin menjamur seiring dengan adanya program BPJS kesehatan ini, klinik yang ada belum memberikan pelayanan yang maksimal kepada masyarakat peserta BPJS melainkan mereka hanya sekedar memberikan pelayanan apa adanya saja.

Pelayanan itu sendiri menurut para ahli merupakan sebuah usaha untuk bagaimana memberikan jasa dalam memenuhi harapan pelanggan (Bambang; 2001), juga disampaikan oleh Suwondo (2001) dalam memberikan pelayanan yang optimal pemeritah perlu melibatkan masyarakat atau sektor swasta untuk berpartisipasi memberikan pelayanan kepada rakyat. Kemudian daripada itu dijelaskan oleh Bambang (2002) pemerintah dalam rangka mewujudkan keinginan rakyat perlu meningkatkan kualitas pelayanan, hal ini akan berdampak kepada kepercayaan rakyat kepada pemerintah di masa depan.

Menurut Abdul Hakim (2001) pelayanan merupakan jenis produk jasa, dimana penciri dari jasa itu adalah tidak tampak, dapat dinikmati pada saat jasa itu diberikan dan sangat berbeda dari satu pelanggan mendapatkan pelayanan dibandingkan dengan pelanggan yangb baik. Dijelaskan oleh Moenir (2000) jasa merupakan sebuah aktivitas orang lain untuk memenuhi kebutuhan atau keinginan orang yang membutuhkan. Untuk dapat memenuhi harapan pasien, sebagai ukuran pelayanan jasa ini menurut Fandy Tjiptono (2004) digunakan ukuran kepuasan pelanggan. Hal ini dikarenakan pelanggan adalah orang yang mendapatkan pelayanan, maka pelanggan tahu pasti berkenaan dengan proses pelayanan mulai awal hingga akhir pelayanan tersebut diberikan. Kemudian juga pelanggan mampu memberikan penilaian yang objektif kepada penyedia jasa karena apa yang dirasakan pelanggan dapat disampaikan dengan gamblang. Kemudian pelanggan juga mampu memberikan data-data yang sesuai dengan kondisi nyata yang dirasakan oleh mereka.

Menurut Gaspersz (1997) pada standar penilaian pelayanan saat ini ilmu yang berkembang mengarah kepada pelanggan, karena pelanggan adalah raja dimana penyedia jasa harus melayani raja hingga mendapatkan kepuasan. Jika tidak maka pelanggan akan berpindah kepada penyedia jasa lainnya. Upaya yang dilakukan dengan membuat standar pelayanan yang jelas dan dapat dilakukan dan ini bentuk kepastian yang diberikan penyedia jasa kepada para pelanggannya.

$$
\text { Selanjutnya Faozan (2003) }
$$

menjelaskan yang menjadi indikator dari kualitas pelayanan sebagai produk jasa antara lain: bukti yang dapat diberikan secara langsung dari pelayanan yang ada dan bukti ini tampak dirasakan pelanggannya. Kemdian kehandala daripada penyedia jasa dalam memberikan pelayanan kepada pasiennya. Tingkat ketanggapan penyedia jasa kepada para pelanggannya terhadap berbagai keluhan yang dirasakan oleh pelangganya selama menerima pelayanan. Juga kesiapa penyedia jasa untuk memberikan jaminan kepada pelanggan bahwa jasa yang diberikan berkualitas.

Menurut Stamatis (dalam Tjiptono; 2004) bahwa dalam model pelayanan yang menggunakan konsep TQS, dimana semua semua pelayanan yang diberikan memiliki standar pelayanan minimal. Dan sistem ini 
secara strategis menjadi ukuran pelayanan untuk mencapai kepuasan pelanggannya.

Menurut Sutopo (2000) indikator pelayanan jasa yang baik terdiri dari beberapa ukuran diantaranya: diberikan dengan petugas yang profesional dengan memiliki keahlian yang sesuai dengan bidangnya, kemudian petugas dalam memberikan pelayanan memiliki perilaku dan sikap yang mendukung sistem pelayanan yang dijanjikan dan juga adanya kemudahan mendapatkan pelayanan itu sendir, kapan saja dan dimana saja berada. Juga memiliki kehandalan dalam memberikan pelayanan serta mumpuni dalam memberikan pelayanan kepada pelangan.

Menurut Kotler (2002) dalam manajemen pemasaran jasa ditegaskan bahwa pelanggan adalah pihak yang harus mendapatkan kepuasan yang diharapkan, dimana pelanggan adalah pihak yang menentukan kualitas baik dan buruknya pelayanan yang diberikan. Mengambil hati pelanggan adalah bagian penting dalam usaha penyedia jasa. Hal ini juga dijelaskan oleh Stamatis (dalam Tjiptono; 2004) bahwa layanan yang berkualitas dengan mengutamakan pelanggannya adalah usaha nyata dalam mana penyedia jasa mampu mencapai keberhasilan.

Menurut Lele dan Sheth (1995) usaha untuk membuat pelanggan puas menjadi sebuah budaya bagi penyedia jasa untuk mendapatkan keberhasilan. Sedangkan (Anomin; 1997) memuaskan pelanggan bukan berarti usaha untuk pelanggan mendapatkan kepuasan dari para pelanggan lainnya, tetapi adalah bagaimana penyedia jasa memberikan apa yang diinginkan pelanggan dengan mengetahui apa yang sesungguhnya yang diinginkan pelanggan tersebut.

Menurut Day dalam (Tjiptono dan Diana; 1995) kepuasan pelanggan menjadi ukuran keberhasilan pelayanan yang diberikan kepada pelanggan oleh penyedia jasa. Menurut Dwiyanto (1995) usaha menilai kepuasan pelanggan terhadap kualitas pelayanan penyedia jasa dapat dilakukan secara sistematis dengan mana apa yang dijanjikan dengan apa yang diberikan dalam rangka memenuhi janji tersebuit.

Menurut Barata (2004) keyakinan terhadap apa yang dianggap tepat oleh penyedia jasa untuk disampaikan kepada pelanggan dengan harapan dapat memuskan pelanggan menjadi bagian penting bagi penyedia jasa. Usaha untuk komitmen terhadap apa yang dijanjikan kepada pelanggan menjadi bagian yang tak terlepaskan dalam rangka mengambil hati pelanggan dan mengharap mereka akan mampu untuk mengkonsumsi kembali kepada penyedia jasa di masa depannya.

Ukuran kualitas pelayanan yang disampaikan Barata (2003) berupa usaha untuk bagaimana menggunakan indiktor diantaranya bagaimana kemampuan yang dimiliki oleh petugas penyedia jasa dalam rangka memberikan pelayanan, kemudian sikap para petugas dalam memberikan pelayanan kepada pelanggannya serta juga dikaitkan dengan penampilan dan juga tindakan yang nyata diberikan kepada pelanggan dalam memenuhi harapan pelanggan. Selain itu juga rasa tanggung jawab daripada petugas pelayanan juga menjadi indikator penting dan hal ini menjadikan penyedia jasa siap mengahapi persaingan.

Menurut Parasuraman (1990) bahwa indikator lain untuk menilai kualitas pelayann adalah bukti dari fasilitas pelayanan fisik penyedia jasa, kemudian adanya usaha iklas petugas pelayanan dalam memberikan pelayanan dan juga tanggap terhadap keinginan pelanggan serta jaminan untuk dapat memenuhi harapan pelanggannya.

Berdasarkan kelima dimensi di atas, jelas bahwa untuk pelayanan yang diberikan oleh klinik menggunakan empat diantaranya yaitu berkenaan dengan 1) prosedur administrasi, 2) pelayanan, 3) fasilitas dan 4) biaya. Menurut Parasuraman (1990) bahwa pelayanan yang berkualitas dapat dilihat dari beberapa dimensi, antara lain: 1) prosedur administrasi, 2) pelayanan, 3) fasilitas dan 4) biaya. 


\section{METODE}

Penelitian ini menggunakan metode kualitatif, yakni dengan melakukan wawancara mendalam kepada informan, yang menjadi informan dalam penelitian ini adalah pengelola klinik pelayanan BPJS di kota Pekanbaru dan juga masyarakat sebagai pelanggan klinik peserta BPJS kesehatan yang mengerti tentang informasi mengenai pelayanan BPJS kesehatan yang mereka rasakan. Pengumpulan data menggunakan wawancara dan data dianalisis dengan teknik analisis kualitatif dengan melakukan cek dan ricek data.

Untuk memastikan data yang diberikan layak untuk ditampilkan dan informan yang menjadi sumber data mewakili seluruh aspek dan mampu memberikan jawaban dari apa yang ditanyakan maka sebelumnya dilakukan uji kelayakan.

\section{HASIL PENELITIAN}

Berdasarkan hasil wawancara dengan petugas klinik dan juga dari masyarakat peserta penjaminan kesehatan (BPJS) mengenai masalah prosedur administrasi sangat erat kaitannya dengan teknis pelayanan sistem kerja adalah: Dari hasil wawancara yang dilakukan dengan petugas pengelola klinik yang melayani peserta BPJS menerangkan bahwa dalam memberikan pelayanan kesehatan kepada masyarakat peserta BPJS kami memiliki prosedur yang jelas dan tegas. Prosedur ini dilakukan, namun terkadang karena keterbatasan sumber daya yang dimiliki prosedur terkadang juga dilewati dan terkadang terlupa.

Hasil wawancara dengan masyarakat yang menerima pelayanan mengenai prosedur tersebut dijelaskan bahwa untuk mendapatkan pelayanan pada klinik masih terhambat oleh pelayanan yang terkadang berbelit-belit, misalnya untuk mendapatkan pelayanan imunisasi saja, kami harus datang ke klinik dan mendaftarkan diri dan tidak hari tersebut dapat imunisasinya dan kami harus pulang dan menunggu konfirmasi dari pihak klinik dan menunggu waktu lama untuk dapat informasi. Dari pihak klinik tidak memberikan informasi jadwal imunisasi yang dilakukan dan akhirnya dari masyarakat yang bertanya lagi, kapan ada waktu imunisasinya dan memakan waktu berminggu-minggu. Pelayanan ini dirasakan berbelit-belit dan kurang melayani dengan baik kepada masyarakat peserta BPJS.

Kemudian mengenai pelayanan yang diberikan klinik kepada masyarakat peserta BPJS berdasarkan hasil wawancara dengan masyarakat menjelaskan bahwa petugas pelayanan bersikap ramah, namun pelayanan yang diberikan kurang memuaskan seperti masalah antrian yang relatif panjang dan juga masalah obat yang kurang lengkap tersedia pada klinik tersebut dan menyebabkan masyarakat mencari obat di apotik dan diluar klinik.

Mengenai fasilitas dalam memberikan pelayanan kepada masyarakat membutuhkan fasilitas yang memadai. Berdasarkan hasil wawancara dengan masyarakat peserta BPJS dalam menerima pelayanan pada klinik pelayanan umum BPJS terlihat bahwa masih terbatasnya ketersediaan petugas kesehatan dalam hal ini adalah dokter yang memberikan pelayanan, dimana dokter yang memberikan pelayanan dominan adalah dokter yang baru temat sekolah dan menyebabkan kepercayaan masyarakat menjadi berkurang dan juga kurangnya fasilitas apotik berupa oba-obatan yang dibutuhkan masyarakat sehingga menjadi keluhan dari masyarakat dalam menerima pelayanan. Selain itu kondisi kebersihan lingkungan klinik yang masih kurang terjaga karena masih banyaknya sampah dan juga lalat di sekitar klinik dan membuat masyarakat risih dan terkadang ada yang berbau tidak sedap.

Terakhir mengenai biaya dalam penyelenggaraan suatu pelayanan membutuhkan biaya sebagai penggerak dari suatu kegiatan pelayanan. Peran biaya sangat penting dalam mencapai keberhasilan suatu kegiatan. Berdasarkan hasil wawancara dengan masyarakat peserta BPJS kesehatan mengenai biaya atau premi 
yang harus dibayarkan kepada BPJS dengan kondisi pelayanan klinik pelayanan BPJS ini dinilai masih belum memadai, karena walaupun di klinik gratis, namun pelayanan yang diberikan masih belum maksimal sehingga masyarakat masih belum puas dan hal ini menjadikan masyarakat terus mengeluh dengan pelayanan yang ada.

\section{PEMBAHASAN}

Berdasarkan uraian dari hasil penelitian yang merupakan gambaran serta diskusi dilanjutkan dengan berbagai pendapat dan bukti lapangan, maka dapat dijelaskan berkaitan dengan kualitas pelayanan pada BPJS di klinik sebagai berikut:

\section{Prosedur administrasi}

Pelayanan administrasi yang diberikan kepada pelanggan BPJS khususnya pada klinik masih belum optimal, dimana setiap pelanggan diharuskan memenuhi beberapa ketentuan administrasi terlebih dahulu padahal dengan adanya kartu BPJS sudah menunjukkan pasien adalah anggota yang berhak mendapatkan pelayanan. Kesan manual dalam era digitalisasi pelayanan masih dirasakan pada klinik.

Berbicara masalah prosedur administrasi sangat erat kaitannya dengan teknis pelayanan sistem kerja, prosedur ini dimulai dari input, proses dan output. Ida Nuraida, S. E. (2008) prosedur administrasi menjadi sebuah ketentuan yang harus dijalani sebelum kegiatan dimulai. Menurut Utami, L. A. (2014) prosedur layanan wajib dilakukan demi tercapai tertib administrasi. Menurut Dimock (1983) prosedur merupakan langkah awal dalam mendapatkan pelayanan yang baik. Juga disampaikan oleh Alwis (2002) prosedur merupakan kegiatan yang secara rutin dikerjakan demi menjamin adanya kesamaan pelayanan yang diberikan kepada pelanggannya. Juga disampaikan oleh Parasuraman (1990) melalui prosedur yang baik akan membuat pelayanan itu dapat diandalkan.

Oktaviani, R. (2008) menjelaskan penggunaan sistem informasi untuk urusan administrasi akan mempermudah dan mempercepat pelayanan. Kameswara, A. D., Christyono, Y., \& Isnanto, R. R. (2013) dan juga Indrajani, I. (2011) berkaitan dengan sistem pelayanan klinik yang terintegrasi bertujuan untuk pelayanan yang efektif dan efisien.

Berdasarkan pendapat tersebut jelas bahwa prosedur dalam konteks administrasi merupakan persyaratan secara administrasi yang diterapkan dalam suatu lembaga pelayanan, administrasi ini sebagai rekaman yang diperuntukkan sebagai analisa dalam pengambilan keputusan. Prosedur administrasi yang baik dapat dilihat dari: 1) mudah dan 2) terjangkau.

Dari penjelasan tersebut, maka jelas dapat diketahui prosedur yang dilakukan oleh klinik dalam memberikan pelayanan kepada masyarakat peserta BPJS memang sudah jelas, namun prosedur tersebut dalam implementasinya kurang dilaksanakan dan membuat masyarakat menjadi terbengkalai dan menunggu lama sehingga masyarakat mengeluh dengan prosedur yang ada. Karena pada prinsipnya prosedur dibuat untuk memudahkan pelayanan dan memberikan jaminan kepada pelanggan akan pelayanan yang berkualitas.

Pelayanan BPJS pada klinik dengan menerapkan prosedur yang panjang, padahal sudah diketahui bahwa pasien adalah anggota dan memiliki kartu BPJS dengan nomor yang dimiliki. Pelanggan dengan menunjukkan kartu BPJS saja semestinya sudah berhak mendapatkan pelayanan pada klinik dengan fasilitas yang dijanjikan seperti dengan dokter yang memiliki kemampuan yang sudah diuji, bukan dokter yang baru lulus kuliah dan terkesan masih muda. Kemudian juga mereka juga sudah berhak mendapatkan obat yang sesuai dengan yang dibutuhkan dan sesuai dengan rekomendasi/resep dokter bukan malah sebaliknya pasien diminta membeli sebagian daripada obat ke apotek.

Kesiapan dari klinik dalam memenuhi standar pelayanan yang dijanjikan pihak BPJS memang menjadi bagian dan seharusnya dilakukan evaluasi 
oleh pihak pemerintah sebagai pengawas jalannya program BPJS itu sendiri. Hal ini diharapkan menjadi dasar perbaikan di masa depannya dalam memuaskan rakyat mendapatkan jaminan berobat.

\section{Pelayanan}

Pelayanan yang diberikan BPJS kepada pasien dalam rangka mendapatkan pelayanan kesehatan pada klinik masih belum optimal, dimana antrian terhadap pelayanan yang diberikan masih terjadi dan juga pelayanan diberikan belum oleh petugas yang meyakinkan pasien, dimana petugas yang memberikan pelayanan masih terkesan belum profesional.

Pelayanan merupakan wujud pemberian pemenuhan kebutuhan dari orang lain. Pelayanan ini menurut Soesilo (2001) adalah upaya memenuhi harapan pelanggannya dengan kegiatan-kegiatan yang tersusun dan sistematis. Kemudian menurut Agus (2001) pelayanan adalah bagian daripada kegiatan proses produksi jasa dan sangat menentukan keberhasilan penyedia jasa. Kemudian disampaikan oleh Khairul (2001) mengarah kepada usaha komersialisasi pelayanan publik kepada masyarakat. Menurut Solichin (2001) reformasi pelayanan publik dalam rangka memenuhi harapan rakyat terhadap haknya mendapatkan jaminan pelayanan yang berkualitas.

Menurut Rasyid (1997) pelayanan pemerintah terkesan kaku kepada rakyat dan hal ini memuat rakyat takut memberikan kritik pada pelayanan yang diberikan. Sedangkan menurut Parasuraman (1990) pelayanan yang baik merupakan pelayanan yang diberikan dengan tindakan yang cepat sesuai prosedur dan bukan ditunda-tunda, kmeudian pelayanan sesuai dengan prosedur yang berlaku serta akurat dalam menangani pelanggannya.

Pada dasarnya menurut Tanudjaya, $\mathrm{P}$. K. (2014); Anas, A., \& Abdullah, A. Z. (2008); Hamidiyah, A. (2013); Aji, W. K., \& Soesanto, H. (2011); dan Anggraeny, C. (2013) pelayanan yang berkualitas diberikan kepada pasien akan meningkatkan kepuasan pasien dan pada gilirannya keberhasilan penyedia jasa juga akan semakin baik pula.

Dari uraian tersebut, menjelaskan bahwa seharusnya pelayanan BPJS pada klinik diberikan sesuai dengan harapan pelanggan, namun dari hasil penelitian masih belum optimal dan perlu mendapatkan berbagai perbaikan seperti perbaikan dalam hal waktu pelayanan yang idealnya sudah berkurangnya antrian dari pelayanan yang seharusnya mereka dapatkan, namun masih adanya antrian panjang. Kemudian pelayanan kesehatan diberikan oleh petugas yang memiliki kemampuan yang mumpuni sesuai dengan penyakit yang diderita pasien, Namun petugas selalu kurang siap melayani pasiennya dan bahkan selalu dilayani oleh para perawatnya saja. Selain itu juga, hasil pelayanan yang terkesan belum optimal dalam melayani pasien dalam hal kesembuhan dan harus berulang-ulang ke klinik.

\section{Fasilitas}

Fasilitas pelayanan pada klinik masih belum optimal seperti mengenai lokasi, sebagian klinik belum menyediakan tempat parkir yang layak dan juga belum tersedia dengan baik sarana pendukung pelayanan yang standar.

Menurut Windy Novia (2005) fasilitas yang baik adalah fasilitas yang dapat memperlancar kegiatan sebuah produk layanan. Kemudian menurut Indrawan (2005) fasilitas yang lengkap menjadi penunjang pelayanan yang optimal. Juga disampaikan Gugup Kismono (2001) bahwa fasilitas yang siap digunakan adalah fasilitas yang menjadi ukuran efektifitas penggunaanya.

Menurut Parasuraman (1990) fasilitas yang baik adalah fasilitas yang sesuai dengan kebutuhan pelayanan, kemudian fasilitas yang memiliki fungsi bila dibutuhkan dan fasilitas yang terbaru serta fasilitas yang lengkap sesuai dengan kebutuhan.

Diketahui menurut Reyhan, A., \& SRI, R. T. A. (2013); Mujiati, M., 
Sugiharti, S., \& Isakh, B. M. (2013); Indonesia, D. K. R. (2008); Nata, D. A. (2013); dan Arias, K. M. (2010) bahwa fasilitas yang memadai akan meningkatkan kualitas pelayanan itu sendiri.

Hal ini apabila dibandingkan dengan pelayanan yang disediakn pada BPJS khususnya pada klinik, masih ditemukan fasilitas yang tidak digunakan dan diletakkan saja tidak digunakan dan bahkan ada fasilitas yang tidak berfungsi, dimana pada saat dibutuhkan diperoleh jawaban alatnya rusak. Hal ini juga kelengkapan fasilitas dan kebaruan dari fasilitas.

Masalah kebaruan fasilitas menjadi kendala, dimana dengan mahalnya peralatan terbaru dan dalam kondisi baru tidak bekas menjadi kendala dari pihak klinik. Sebagian klinik menggunakan peralatan bekas yang masih bisa dipakai. Hal ini menjadikan pelayanan pada klinik menjadi belum optimal.

Oleh karenanya maka pihak BPJS perlu melakukan pengawasan secara terpadu dalam rangka memastikan kelayakan klinik memberikan pelayanan kepada pelanggan BPJS, sehingga hal ini dapat membuat BPJS mendapatkan hati dari para pelanggannya dan juga menjadikan para pelanggan menaruh kepercayaan kepada BPJS dalam mendapatkan pelayanan kesehatan.

\section{Biaya}

Berkaitan dengan biaya, pada dasarnya pembiayaan pelayanan pada BPJS sudah dibayarkan sebelum pasien mendapatkan pelayanan kesehatan. Namun pada kenyataan di lapangan berkaitan dengan biaya, pasien tetap diharuskan mengeluarkan biaya tambahan seperti untuk membelu obat di apotik. Hal ini membuat pasien juga kurang efektif dalam mendapatkan pelayanan kesehatan.

Menurut Blocher (2007) biaya memang menjadi bagian penting dalam mendapatkan pelayanan yang baik. Terry (2003) menjelaskan melalui pengaturan pembiayaan akan mempermudah pelanggan mendapatkan pelayanan. Menurut Amin Wijaya Tunggal (2007) biaya menjadi jaminan untuk mendapatkan pelayanan berkualitas.

Menurut Mulyasa (2004) efektifitas dan efisiensi dalam pelayanan membutuhkan biaya. Parasuraman (1990) memberikan ukuran biaya yang baik dalam mendapatkan pelayanan diantaranya adanya kejelasan biaya yang dikeluarkan pelanggan saat mendapatkan pelayanan, kemudian adanya keterjangkauan biaya yang seharusnya dikeluarkan dan disesuai dengan kemampuan pelanggan dan adanya kesesuaian antara jasa yang diberikan dengan biaya yang dikeluarkan.

Penyediaan biaya yang terjamin menurut Janis, N. (2014); Yustisia, T. P. (2014); Safriantini, D. (2014); dan Yustiawan, T. (2013) akan mendorong pelayanan yang berkualitas diberikan pihak penyedia jasa kesehatan.

Diskusi yang diarahkan mengatakan bahwa pembiayaan BPJS yang diberikan pihak BPJS terkadang mengalami keterlambatan pembayaran, sehingga klinik harus mengeluarkan talangan biaya untuk memenuhi kebutuhan penyediaan jasa seperti pembayaran karyawan dan juga pembelian obat-obatan. Selain itu juga pembayaran BPJS dianggap sebagai bentuk pelayanan gratis, padahal pasien diwajibkan melakukan pembayaran secara terus menerus, setiap bulan dan apabila pembayaran tidak lancara maka pelayanan tidak diberikan kepada pasien.

Hal inilah yang menjadi kendala yang dirasakan olah pasien dan pihak klinik dalam rangka membahas masalah biaya. Sebaiknya pihak BPJS memberikan hak pembiayaan kepada klinik dengan melakukan pembayaran jasa tepat waktu. Sehingga pihak klinik dapat memberikan pelayanan yang berkualitas kepada pasien.

\section{SIMPULAN}

Kualitas pelayanan kesehatan pada fasilitas klinik yang memberikan pelayanan BPJS kepada masyarakat di Kota Pekanbaru dinilai masih belum optimal dan hal ini karena prosedur pelayanan yang kurang diterapkan dengan baik dan juga 
karena pelayanan yang diberikan belum menggunakan orang-orang yang tepat dan juga fasilitas yang belum lengkap, walaupun biaya yang ditetapkan sudah murah namun belum efisien dalam membuat masyarakat sembuh dari penyakitnya.

\section{DAFTAR RUJUKAN}

Abdul Hakim, 2001, Konflik dalam Organisasi dan Kaitannya dengan Kualitas Pelayanan Publik, Dalam Jurnal Administrasi Negara (Volume 1 No. 2 Maret 2001), FIA Unibraw, Malang.

Agus Dwiyanto, 2002, Reformasi Birokrasi Publik di Indonesia, Yogyakarta: Pusat Studi Kependudukan dan Kebijakan UGM.

Agus Suryono, 2001, Budaya Birokrasi Pelayanan Publik, Dalam Jurnal Administrasi Negara (Volume 1 No. 2 Maret 2001), FIA Unibraw, Malang.

Aji, W. K., \& Soesanto, H. (2011). Analisis Pengaruh Kualitas Pelayanan, Harga dan Fasilitas terhadap Kepuasan Pasien (Studi Pada Pasien Klinik As Syifa di Kab. Bekasi) (Doctoral dissertation, Universitas Diponegoro).

Amin Wijaya Tunggal, 2007, Manajemen Biaya Terpadu, Jakarta: Harvarindo

Anas, A., \& Abdullah, A. Z. (2008). Studi Mutu Pelayanan Berdasarkan Kepuasan Pasien di Klinik gigi dan Mulut RSUP Dr Wahidin Sudirohusodo Makasar. Dentofasial Jurnal Kedokteran Gigi, 7(2), 105.

Anggraeny, C. (2013). Inovasi Pelayanan Kesehatan dalam Meningkatkan

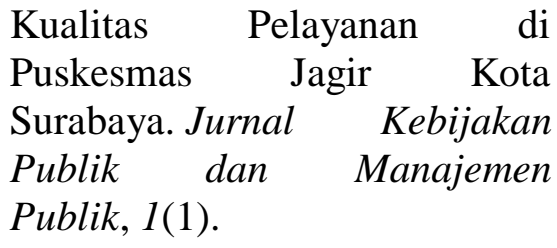

Anonim, 1997, Customer Service, Astek dan Asuransi Jasa Raharja, Jakarta.

Arias, K. M. (2010). Investigasi dan pengendalian wabah di fasilitas pelayanan kesehatan. EGC.

Atep Adya Barata, 2003, Dasar-dasar Pelayanan Prima, (Persipan Membangun Budaya Pelayanan Prima untuk Meningkatkan Kepuasan dan Loyalitas Pelanggan). Jakarta: Elex Media Komputindo.

Bambang Supriyono, 2001, Responsivitas dan Akuntabilitas Sektor Publik, Dalam Jurnal Administrasi Negara (Volume 1 No. 2 Maret 2001), FIA Unibraw, Malang.

Blocher, 2007, Cost Management (Manajemen Biaya) Penekanan strategis, Jakarta: Salemba Empat

Fandy Tjiptono, 2004, Prinsip-prinsip Total Quality Service. Yogyakarta: Andi Offset.

Gasperz, Vincent, 1997, Manajemen Kualitas Penerapan Konsepkonsep Kualitas dalam Manajemen Bisnis Total, Jakarta: PT. Gramedia Pustaka Utama.

Gugup Kismono, 2001, Pengantar Bisnis, Yogyakarta: BPFE.

Hamidiyah, A. (2013). Hubungan persepsi pasien tentang kualitas 
pelayanan dengan minat kunjungan ulang di klinik umum rumah sakit bhineka bakti husada kota tangerang selatan tahun 2013.

Haris Faozan, 2003, Peranan Birokrasi, Manajemen Kebijakan dan Eksistensi Pelayanan Publik (Teropong Fenomena dan Tawaran Jalan Alternatif), Jakarta: Pusat Kajian Kinerja Kelembagaan Administrasi Negara.

Ida Nuraida, S. E. (2008). Manajemen administrasi perkantoran. Kanisius.

Indonesia, D. K. R. (2008). Pedoman manajerial pencegahan dan pengendalian infeksi di rumah sakit dan fasilitas pelayanan kesehatan lainnya. Jakarta: Departemen Kesehatan RI.

Indrajani, I. (2011). Perancangan Sistem Basis Data pada Klinik. ComTech: Computer, Mathematics and Engineering Applications, 2(1), 218-228.

Indrawan, Kamus Lengkap Bahasa Indonesia, Jombang: Lintas Media.

Janis, N. (2014). BPJS Kesehatan, Supply, dan Demand Terhadap Layanan Kesehatan. Depkeu. Jakarta.

Kameswara, A. D., Christyono, Y., \& Isnanto, R. R. (2013). Perancangan Sistem Administrasi Dan Rekam Medis Klinik Gigi. TRANSIENT, 2(3), 679.

Kotler, Philip, 2002, Manajemen Pemasaran, Alih Bahasa Hendra Teguh, Rony
A. Rusli dan Benyamin Molan, Prenhallindo, Jakarta.

Moenir, 2000, Manajemen Pelayanan Umum di Indonesia, Bumi Aksara, Jakarta.

Mujiati, M., Sugiharti, S., \& Isakh, B. M. (2013). Gambaran Pelaksanaan Layanan Voluntary Counseling And Testing (VCT) dan Sarana Prasarana Klinik VCT di Kota Bandung Tahun 2013. Jurnal Kesehatan Reproduksi, 4(3 Des), 153-160.

Mulyasa, 2007, Manajemen Berbasis Sekolah Konsep, Strategi dan Implementasi, Bandung : Rosda Karya.

Nata, D. A. (2013). Analisis Ketersediaan dan Pola Sebaran Spasial Fasilitas Kesehatan Terhadap Tingkat Kepuasan Pelayanan Kesehatan Masyarakat di Kecamatan Rembang. GeoImage, 2(2).

Novia Winda, 2005, Kamus Lengkap Bahasa Indonesia, Surabaya: Kahiko.

Oktaviani, R. (2008). Rancangan Sistem Informasi Administrasi Rawat Jalan pada Klinik Bhakti Kopetri dengan Metodologi Berorientasi Objek. Diambil dari: $\quad$ http://sippendidikan. org/file_upload/jurnal. pdf.(16 Mei 2014), 8.

Reyhan, A., \& SRI, R. T. A. (2013). Analisis Pengaruh Kualitas Pelayanan, Fasilitas, dan Kepercayaan terhadap Kepuasan Konsumen (Studi pada Perusahaan Cito Laboratorium Klinik Semarang Cabang Indraprasta) (Doctoral 
dissertation, Fakultas Ekonomika dan Bisnis).

Safriantini, D. (2014). Analisis besaran biaya kapitasi dan premi programjaminankesehatanpt. Jamsostek berdasarkan biaya klaim dan utilisasi pelayanan (studi kasus pt. Jamsostek daerah istimewa yogyakarta) (Doctoral dissertation, Universitas Gadjah Mada).

Soesilo Zauhar, 2001, Administrasi Pelayanan Publik: Sebuah Perbincangan Awal, dalam Jurnal Administrasi Negara (Volume 1 No. 2 Maret 2001), Malang: FIA Unibraw.

Sutopo, dkk, 2000, Pelayanan Prima, Lembaga Administrasi Negara, Jakarta.

Suwondo, 2001, Desentralisasi Pelayanan Publik: Hubungan Komplementer antara sektor Negara, Mekanisme Pasar dan Organisasi Non Pemerintah, dalam Jurnal Administrasi Negara (Vol. 1 No. 2 Maret 2001) Malang : FIA Unibraw.

Tanudjaya, P. K. (2014). Pengaruh kualitas pelayanan klinik gigi terhadap kepuasan dan kepercayaan pasien sehingga meningkatkan keinginan untuk berobat kembali. Jurnal Manajemen dan pemasaran jasa, 7(1), 39-60.

Terry, GR, 2003, Prinsip-prinsip manajemen,Jakarta: Bumi Aksara

Undang-Undang Republik Indonesia Nomor 32 Tahun 2004 Tentang Pemerintahan Daerah.

Utami, L. A. (2014). Sistem Informasi Administrasi Pasien pada Klinik
Keluarga Depok. Konferensi Nasional Ilmu Pengetahuan dan Teknologi, 1(1), 33-38.

Yustiawan, T. (2013). Clinic Management In Term Of Preparing Cooperation With Social Health Insurance Provider. Jurnal Administrasi Kesehatan Indonesia, 1(3).

Yustisia, T. P. (2014). Panduan Resmi Memperoleh Jaminan Kesehatan dari BPJS. VisiMedia.

Zauhar, Susilo, 2001, Administrasi Pelayanan Publik: sebuah Perbincangan Awal, dalam Jurnal Administrasi Negara (Vol.1 No.2 Maret 2001), FIA Unibraw, Malang. 